\title{
KLRC1 Gene
}

National Cancer Institute

\section{Source}

National Cancer Institute. KLRC1 Gene. NCI Thesaurus. Code C104362.

This gene is involved in the regulation of immune responses. 